\title{
TINGKAT PENGETAHUAN, SIKAP, DAN KEINGINAN SUAMI DARI PASANGAN USIA SUBUR TERHADAP METODE KONTRASEPSI VASEKTOMI DI KECAMATAN DENPASAR SELATAN TAHUN 2017
}

\author{
Kadek Diah Wulandari*, Ketut Hari Mulyawan, Desak Nyoman Widyantini \\ Program Studi Kesehatan Masyarakat Fakultas Kedokteran Universitas Udayana \\ *Email: wulandaridiah951@yahoo.co.id
}

\begin{abstract}
ABSTRAK
Kota Denpasar merupakan salah satu daerah yang memiliki akseptor Keluarga Berencana (KB) pria (vasektomi) terendah di Provinsi Bali dengan akseptor rate tahun 2015 sebesar 0,0013. Tujuan dari penelitian ini untuk mengetahui pengetahuan, sikap dan keinginan suami dari pasangan usia subur (PUS) terhadap metode kontrasepsi vasektomi di Kecamatan Denpasar Selatan Tahun 2017. Penelitian ini merupakan cross sectional deskriptif yang dilakukan pada suami dari pasangan usia subur (PUS) di wilayah Kecamatan Denpasar Selatan tahun 2017 sebanyak 62 sampel yang memenuhi kriteria menjadi akseptor vasektomi, yang dipilih secara multistage random sampling dari 326 pasangan usia subur (PUS) yang berdomisili di 10 desa/kelurahan di Kecamatan Denpasar Selatan. Data pengetahuan, sikap dan keinginan menggunakan metode wawancara dan dianalisis secara deskriptif. Hasil penelitian menunjukkan sebanyak 9,7\% suami dari pasangan usia subur (PUS) berkeinginan menjadi akseptor vasektomi, sebanyak 66,1\% memiliki pengetahuan kurang dan sebanyak $72,6 \%$ memiliki sikap positif terhadap kontrasepsi vasektomi. Dari penelitian ini dapat disimpulkan bahwa lebih dari setengah responden memiliki pengetahuan yang rendah dan tidak berkeinginan terhadap metode kontrasepsi vasektomi Diharapkan kepada petugas kesehatan khususnya BKKBN dapat memberikan sasaran penyuluhan yang lebih mengkhusus kepada masyarakat dengan kelompok umur 35-45 tahun dan diharapkan dapat memberikan informasi sedini mungkin tentang kontrasepsi vasektomi bagi pasangan suami istri.
\end{abstract}

Kata Kunci: Pengetahuan, Sikap, Keinginan, Metode Kontrasepsi Vasektomi, Suami dari Pasangan Usia Subur (PUS)

\begin{abstract}
Denpasar City is one of the regions that has the lowest male family planning (KB) acceptor (vasectomy) in Bali with an acceptor rate of 0.0013 in 2015 . The purpose of this study was to determine the knowledge, attitudes and desires of husbands of fertile age couples (PUS) to vasectomy contraceptive methods in the South Denpasar District in 2017. This study use a descriptive cross sectional study conducted on husbands of fertile age couples (PUS) in the District area South Denpasar in 2017 as many as 62 samples that met the criteria of being a vasectomy acceptor, were selected by multistage random sampling from 326 fertile age couples (PUS) who are domiciled in 10 villages / sub-districts in South Denpasar District. Knowledge data, attitudes and desires using the interview method and analyzed descriptively. The results showed $9.7 \%$ of husbands of fertile age couples (PUS) wanted to be vasectomy acceptors, $66.1 \%$ had less knowledge and $72.6 \%$ had positive attitudes towards vasectomy contraception. From this study it can be concluded that more than half of respondents have low knowledge and do not wish to have vasectomy contraception methods. It is expected that health workers, especially BKKBN, can provide counseling targets that are more specific to people in the age group of 35-45 years and are expected to provide information as early as possible about vasectomy contraception for married couples. Keywords: Knowledge, Attitude, Desire, Vasectomy Contraception Method, Husband of a Fertile Age Partner (PUS)
\end{abstract}

\section{PENDAHULUAN}

Kota Denpasar merupakan salah satu daerah yang memiliki akseptor Keluarga Berencana (KB) pria terendah di Provinsi Bali dan ada kecenderungan penurunan jumlah akseptor dalam dua tahun terakhir. Jika dibandingkan dengan Kabupaten lain seperti Tabanan yang juga memiliki jumlah akseptor KB pria yang rendah. Tahun 2015 jumlah akseptor KB vasektomi di Kota Denpasar sebesar 96 akseptor, dari total akseptor KB di Kota Denpasar sebesar 69.786 akseptor dengan cakupan sebesar 5\%. Dalam beberapa tahun terakhir di Kota Denpasar terjadi penurunan akseptor $\mathrm{KB}$ vasektomi dibandingkan akseptor $\mathrm{KB}$ 
kondom. Tahun 2014 jumlah akseptor KB aktif pria sebesar 76.805 akseptor dengan $4,4 \%$ adalah pengguna akseptor KB kondom dan hanya $0,1 \%$ yang merupakan akseptor vasektomi (Dinas Kesehatan Provinsi Bali, 2015)

Kota Denpasar merupakan salah satu wilayah yang memiliki pertumbuhan penduduk yang tinggi dan cenderung mengalami peningkatan dalam beberapa tahun terakhir. Pada tahun 2015 Badan Pusat Statistik Kota Denpasar mencatat jumlah penduduk di Kota Denpasar sebesar 880.600 jiwa dengan laju pertumbuhan penduduk 1,97\%, dengan jumlah Pasangan Usia Subur (PUS) sebesar 86.175 penduduk. Kepesertaan akseptor KB masih didominasi oleh jenis KB wanita, seperti IUD (Intra Uterine Device), implant, MOW, suntik dan pil dibandingkan metode kontrasepsi pria, seperti vasektomi dan kondom (Badan Pusat Statistik Kota Denpasar, 2015). Pada tahun 2015 Kecamatan Denpasar Selatan merupakan salah satu daerah yang jumlah akseptor vasektomi yang rendah, yaitu hanya sebesar 10 akseptor (0,10\%) dari 17.478 akseptor dibandingkan dengan kecamatan lain di Kota Denpasar seperti Kecamatan Denpasar Utara, Denpasar Barat dan Denpasar Timur

Banyak faktor yang mempengaruhi masih rendahnya cakupan akseptor vasektomi, diantaranya masih banyak masyarakat yang mempunyai persepsi yang salah tentang vasektomi, yaituvasektomi dapat berdampak terhadap fungsi seksual (disfungsi seksual), selain itu adanya persepsi tindakan operasi yang menyeramkan, vasektomi sama dengan infertil (mandul), dapat membuat pria impotensi, dapat menurunkan gairah seksual (libido), membuat pria tidak bisa ejakulasi, pria atau suami dapat dengan mudah untuk selingkuh dan beberapa pria cemas terhadap prosedur pelaksanaan vasektomi. Ada anggapanpula bahwa pria yang sudah di vasektomi akan kehilangan gairah seksual, padahal yang berbeda setelah vasektomi hanya sperma tidak keluar saat ejakulasi, untuk mencegah terjadinya kehamilan.Padahal metode ini merupakan metode kontrasepsi yang sangat efektif dan aman untuk mencegah kehamilan. Kurangnya sosialisasi menyebabkan pemahaman tentang vasektomi keliru sehingga pria yang melakukan vasektomipun rendah (Fitri, Mir'atul. dkk, 2012) Faktor pengetahuan pasangan usia subur (PUS) memiliki peranan penting terhadap keikutsertaan dalam kontrasepsi vasektomi. Berdasarkan penelitian di Kecamatan Rancaekek Tahun 2012 tentang vasektomi sebanyak $26,5 \%$ yang memiliki pengetahuan yang baik tentang vasektomi (Nurrita, dkk, 2012). Berdasarkan hal tersebut, maka penulis tertarik melakukan penelitian tentang "Tingkat Pengetahuan, Sikap dan Keinginan Suami dari Pasangan Usia Subur (PUS) Terhadap Metode Kontrasepsi Vasektomi Di Kecamatan Denpasar Selatan Tahun 2017"

\section{METODE}

Penelitian ini merupakan penelitian metode deskriptif kuantitatif dengan rancangan cross sectional. Data dikumpulkan pada suatu waktu tertentu untuk menggambarkan keadaan dan kegiatan pada waktu tertentu. Penelitian 
ini dilaksanakan di Kecamatan Denpasar Selatan, dimana akan diambil beberapa pasangan usia subur (PUS) di masingmasing Wilayah Kerja Puskesmas di Denpasar Selatan secara acak atau random. Penelitian ini dilaksanakan selama 2 bulan, yaitu Bulan Maret sampai dengan April 2017.

Penelitian ini menggunakan metode multistage random sampling yaitu sistem pengambilan sampel yang dilakukan secara bertingkat dan dilakukan dengan melakukan pengundian sehingga didapatkan dari empat puskesmas di Kecamatan Denpasar Selatan, dua puskesmas diantaranya dipilih secara random menjadi sampel yang masingmasing mewilayahi dua desa atau kelurahan. Desa atau kelurahan tersebut antara lain Desa Sidakarya, Kelurahan Panjer, Kelurahan Renon dan Kelurahan Sanur. Masing-masing desa atau kelurahan dipilih secara random dua banjar atau

Tabel 1 Distribusi Frekuensi Karakteristik Suami dari Pasangan Usia Subur (PUS) di Kecamatan Denpasar Selatan Tahun 2017

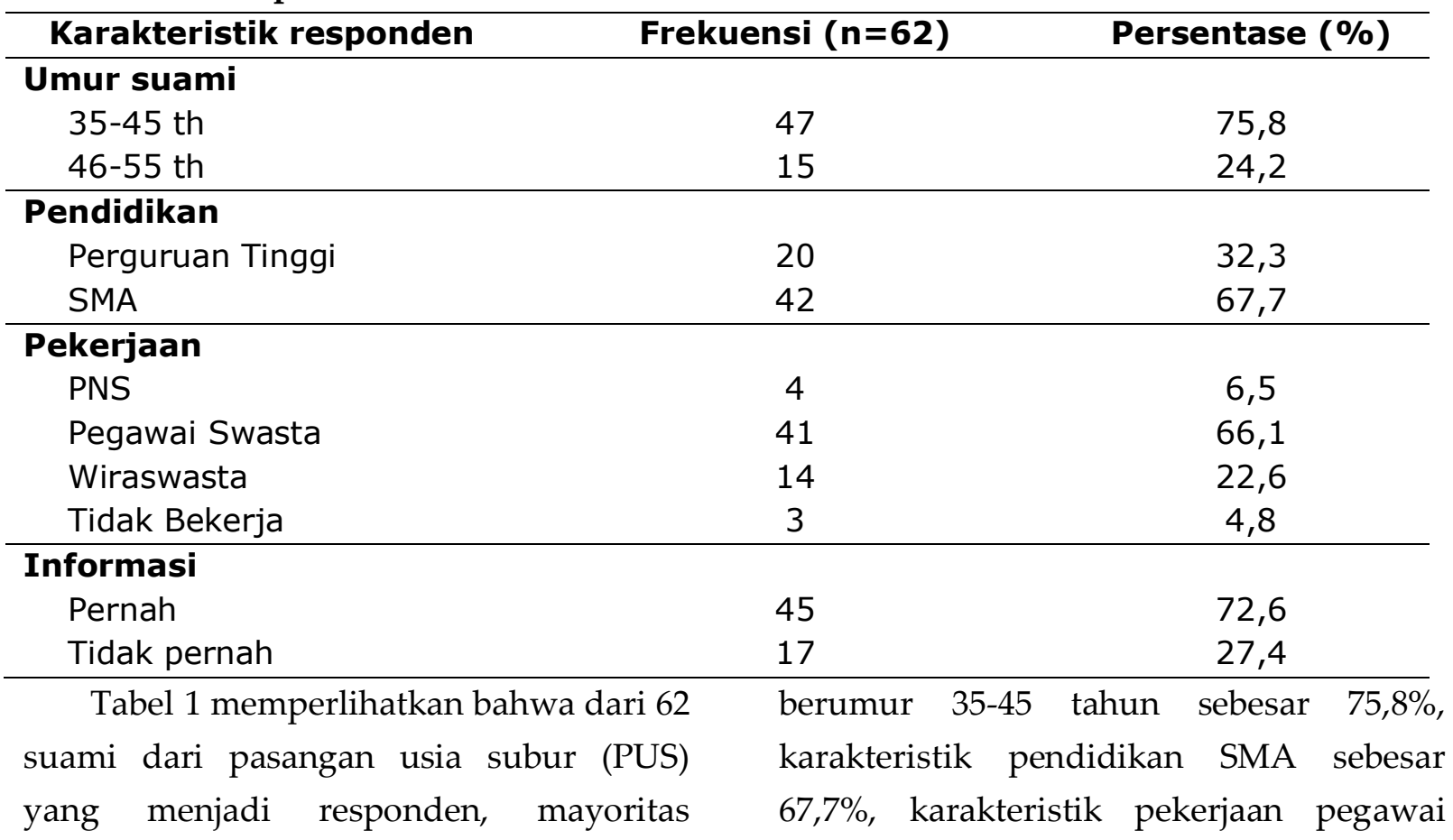


swasta sebesar $66,1 \%$ dan sebanyak $72,6 \%$ pernah mendengar informasi tentang kontrasepsi vasektomi.

Keinginan Suami Dari Pasangan Usia Subur (PUS)

Tabel 2 Distribusi Frekuensi Keinginan Suami dari Pasangan Usia Subur (PUS) Terhadap Metode Kontrasepsi Vasektomi Tahun 2017

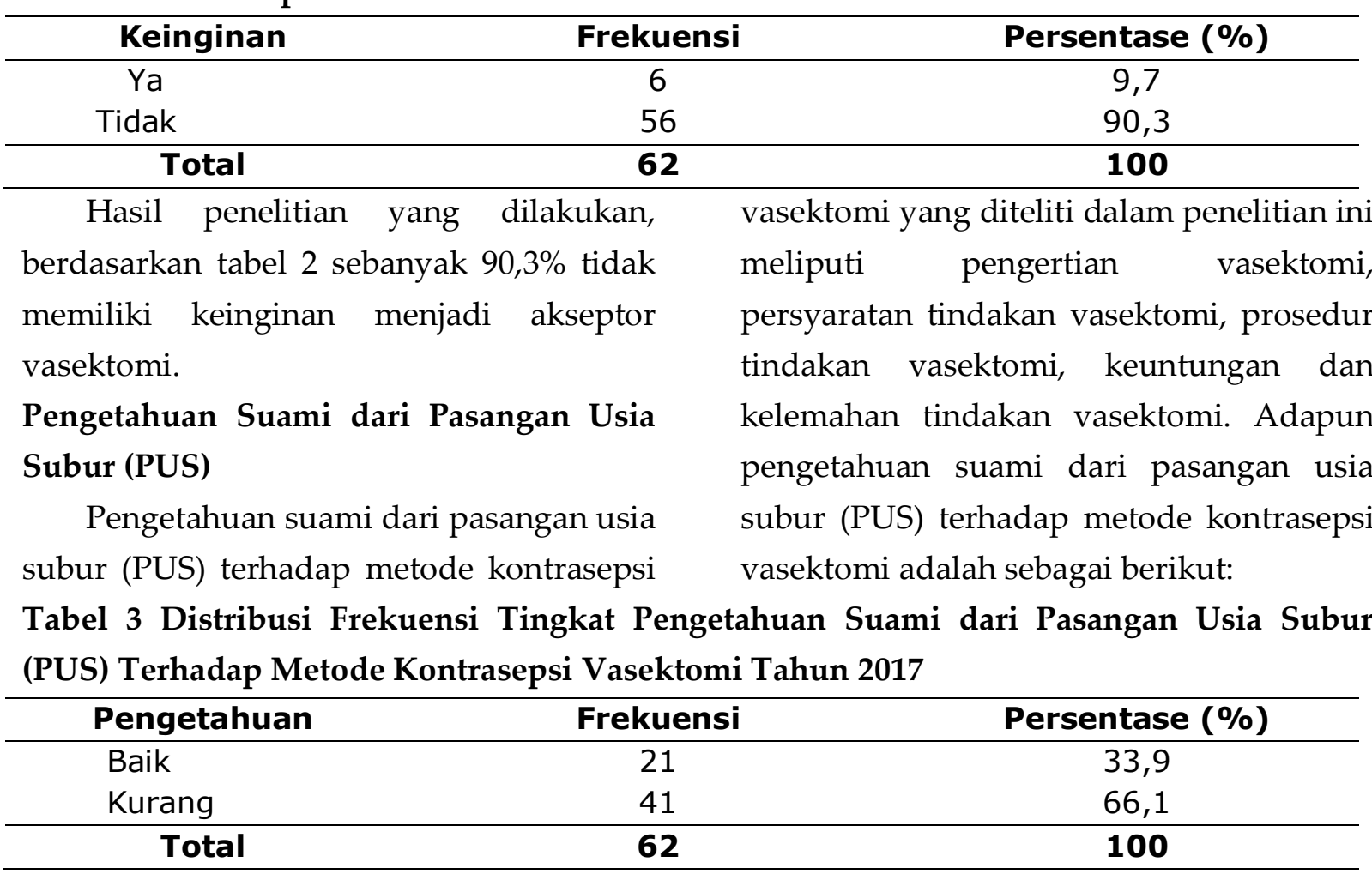

Hasil dari penelitian yang dilakukan, berdasarkan Tabel 3 bahwa sebagian besar responden memiliki pengetahuan kurang terhadap kontrasepsi vasektomi sebesar $66,1 \%$. Keinginan suami dari pasangan usia

Tabel 4 Distribusi Frekuensi Suami dari Pasangan Usia Subur (PUS) yang Berkeinginan dengan Pengetahuan Terhadap Metode Kontrasepsi Vasektomi di Kecamatan Denpasar Selatan Tahun 2017 Berdasarkan Karakteristik Responden

\begin{tabular}{lcc}
\hline \multirow{2}{*}{ Karakteristik Responden } & \multicolumn{2}{c}{ Berkeinginan } \\
\cline { 2 - 3 } & $\begin{array}{c}\text { Pengetahuan Baik } \\
\mathbf{f ( \% )}\end{array}$ & $\begin{array}{c}\text { Pengetahuan Kurang } \\
\mathbf{f}(\%)\end{array}$ \\
\hline Umur & $0(0,0)$ & $0(0,0)$ \\
$35-45$ th & $2(33,9)$ & $4(66,1)$ \\
$46-55$ th & & \\
Pendidikan & $0(0,0)$ & $0(0,0)$ \\
Perguruan Tinggi & $2(33,9)$ & $4(66,1)$ \\
SMA & &
\end{tabular}




\begin{tabular}{l} 
Pekerjaan \\
PNS \\
Pegawai Swasta \\
Wiraswasta \\
Tidak Bekerja \\
Informasi \\
Pernah \\
Tidak Pernah \\
\hline \multicolumn{2}{c}{ Berdasarkan Tabel 4 menunjukkan } \\
bahwa dari responden yang berkeinginan \\
terhadap kontrasepsi vasektomi sebagian \\
besar memiliki pengetahuan kurang \\
sebesar 66,1\% yang berada pada \\
kelompok umur $46-55$ tahun dengan
\end{tabular}

Tabel 5 Distribusi Frekuensi Suami dari Pasangan Usia Subur (PUS) yang Tidak Berkeinginan dengan Pengetahuan Terhadap Metode Kontrasepsi Vasektomi di Kecamatan Denpasar Selatan Tahun 2017 Berdasarkan Karakteristik Responden

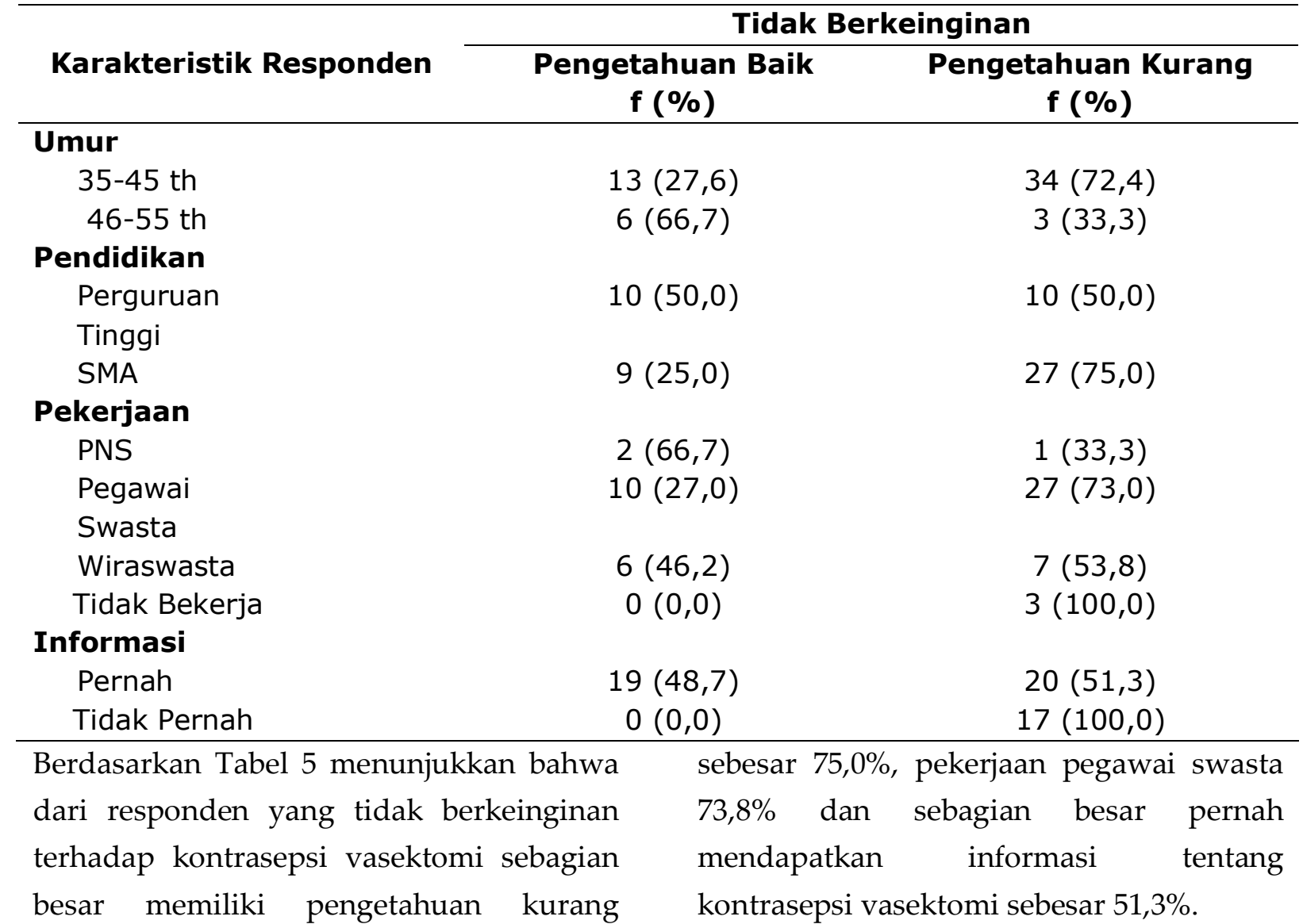
sebesar $72,4 \%$ pada kelompok umur $35-45$ tahun, karakteristik pendidikan SMA Sikap Suami Dari Pasangan Usia Subur (PUS) Terhadap Metode Kontrasepsi Vasektomi Tabel 6 Distribusi Frekuensi Sikap Suami dari Pasangan Usia Subur (PUS) Terhadap Metode Kontrasepsi Vasektomi Tahun 2017 


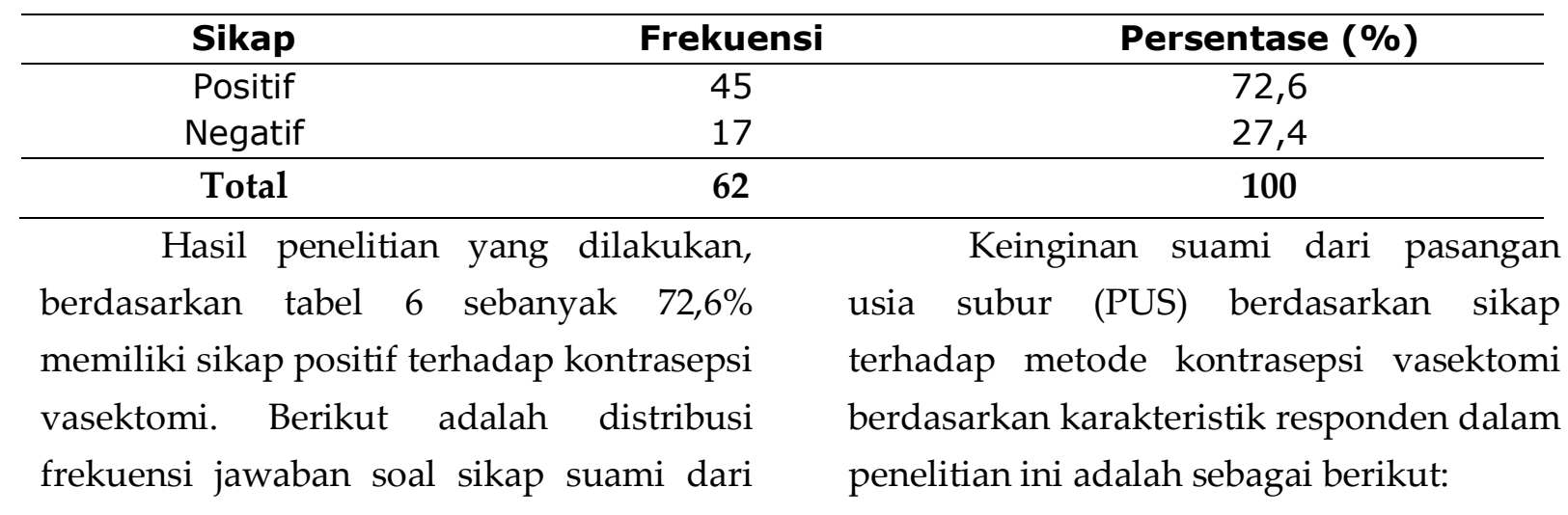
pasangan usia subur (PUS) terhadap metode kontrasepsi vasektomi.

Tabel 7 Distribusi Frekuensi Suami dari Pasangan Usia Subur (PUS) yang Berkeinginan dengan Sikap Terhadap Metode Kontrasepsi Vasektomi di Kecamatan Denpasar Selatan Tahun 2017 Berdasarkan Karakteristik Responden

\begin{tabular}{|c|c|c|}
\hline \multirow[b]{2}{*}{ Karakteristik Responden } & \multicolumn{2}{|c|}{ Berkeinginan } \\
\hline & $\begin{array}{c}\text { Sikap Positif } \\
\text { f }(\%)\end{array}$ & $\begin{array}{c}\text { Sikap Negatif } \\
\text { f }(\%)\end{array}$ \\
\hline \multicolumn{3}{|l|}{ Umur } \\
\hline $35-45$ th & $0(0,0)$ & $0(0,0)$ \\
\hline $46-55$ th & $6(100,0)$ & $0(0,0)$ \\
\hline \multicolumn{3}{|l|}{ Pendidikan } \\
\hline Perguruan Tinggi & $0(0,0)$ & $0(0,0)$ \\
\hline SMA & $6(100,0)$ & $0(0,0)$ \\
\hline \multicolumn{3}{|l|}{ Pekerjaan } \\
\hline PNS & $1(100,0)$ & $0(0,0)$ \\
\hline Pegawai Swasta & $4(100,0)$ & $0(0,0)$ \\
\hline Wiraswasta & $1(100,0)$ & $0(0,0)$ \\
\hline Lain-lain & $0(0,0)$ & $0(0,0)$ \\
\hline \multicolumn{3}{|l|}{ Informasi } \\
\hline Pernah & $6(100,0)$ & $0(0,0)$ \\
\hline Tidak Pernah & $0(0,0)$ & $0(0,0)$ \\
\hline
\end{tabular}

Tabel 7 menunjukkan dari semua tahun, pendidikan SMA, sebagian besar responden yang berkeinginan terhadap pada karakteristik pekerjaan pegawai kontrasepsi vasektomi semuanya memiliki swasta dan pernah mendapatkan informasi sikap positif pada kelompok umur 46-55 terhadap kontrasepsi vasektomi.

Tabel 8 Distribusi Frekuensi Suami dari Pasangan Usia Subur (PUS) yang Tidak Berkeinginan dengan Sikap Terhadap Metode Kontrasepsi Vasektomi di Kecamatan Denpasar Selatan Tahun 2017 Berdasarkan Karakteristik Responden

\begin{tabular}{lcc}
\hline \multirow{2}{*}{ Karakteristik Responden } & \multicolumn{2}{c}{ Tidak Berkeinginan } \\
\cline { 2 - 3 } & $\begin{array}{c}\text { Sikap Positif } \\
\mathbf{f ~ ( \% )}\end{array}$ & $\begin{array}{c}\text { Sikap Negatif } \\
\mathbf{f}(\%)\end{array}$ \\
\hline Umur & $32(68,0)$ & $15(32,0)$ \\
$35-45$ th & $7(77,8)$ & $2(22,2)$ \\
$46-55$ th &
\end{tabular}




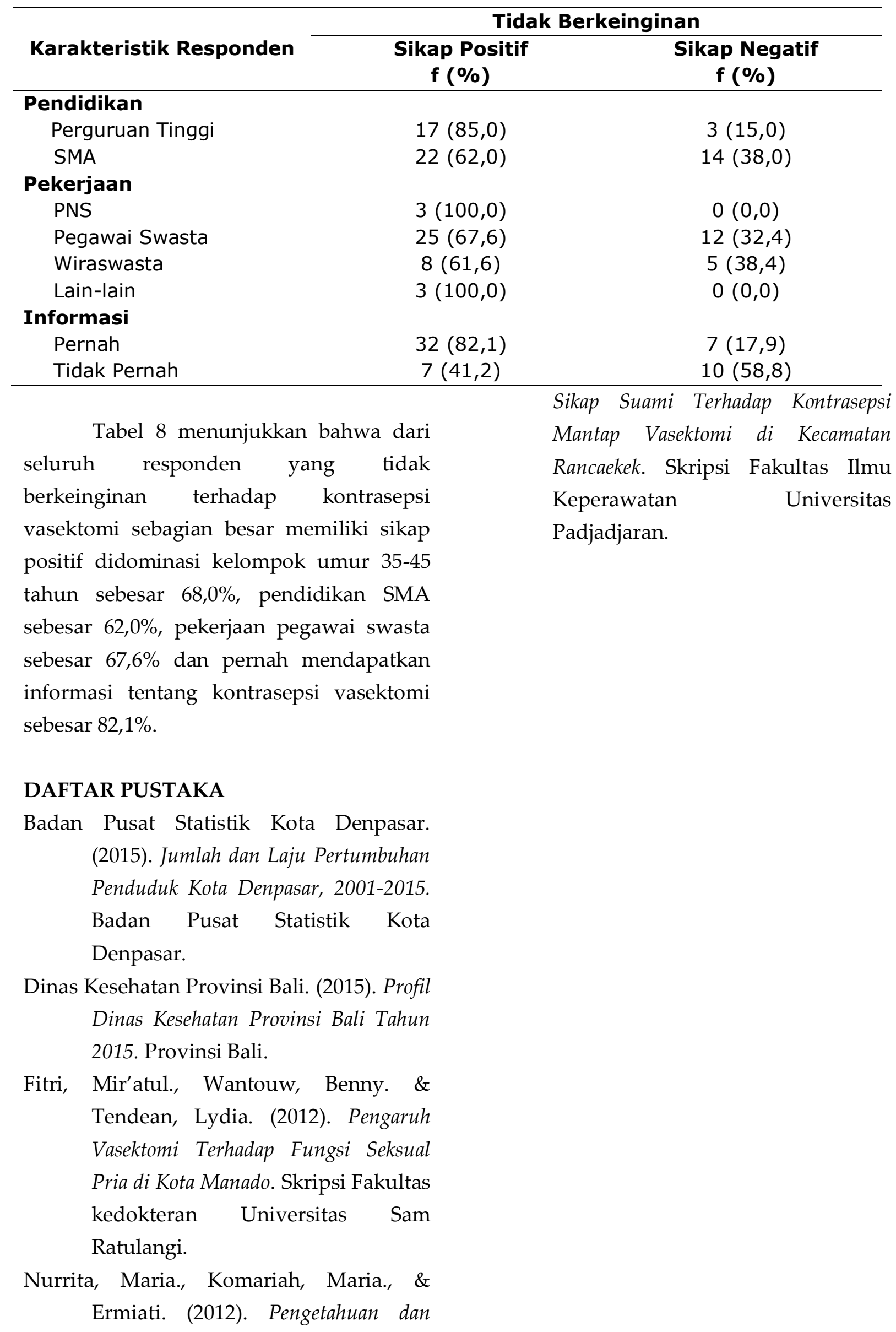

